\title{
Blended Learning: study of a formative assessment in the flipped classroom model
}

\author{
Ana Cristina Gomes Santos Hostt \\ $\mathrm{PhD}$ in Immunology from the Federal University of Minas Gerais - UFMG. \\ Specialist in Teaching and Learning in Higher Education from Tampere University (Finland). \\ Professor in undergraduate courses at UNA.
}

\section{Juliana Lopes de Almeida Souza}

PhD student in Social Communication from the Federal University of Minas Gerais - UFMG. Specialist in Teaching and Learning in Higher Education from Tampere University (Finland). Professor in undergraduate and postgraduate courses at UNA and PUC.

\section{Jane Leroy Evangelista}

Master in Administration, Competitiveness and Innovation from the Pedro Leopoldo Foundation. Undergraduate Professor in Creative Economy courses at UNA University Center and postgraduate in Branding at PUC-Minas.

\begin{abstract}
Summative and formative assessments are important for students' learning pathway. The article analyzes the blended learning model in the Entrepreneurship discipline, in two classes from the perspective of a learning experience as formative assessment, applied in the online platform. The study pointed out that students' access to content increases when participation is stimulated through a formative activity in the online environment. In the class of 54 students, 37 students performed the activity, while in the other class of 76 students, 67 students performed the activity in the online environment.
\end{abstract}

Key-Words: formative assessment, blended learning, learning experience, flipped classroom.

INTRODUCTION TO THE BLENDED LEARNING MODEL.

The research analyzes the blended learning model used by Anima, from the establishment of online and classroom teaching and learning experiences, and how they can even lead to the interconnectedness of these environments. In this context, it is interesting to note the innovation in the learning process of students. In Anima Group, the hybridization of teaching was established in the subjects of the presential courses, which curriculums present $20 \%$ of learning in the online environment. In some disciplines, in the current curriculum, blended education integrates the Anima Learning Ecosystem in its Higher Education Institutions (HEIs). This current curriculum is a competency-based teaching proposal. This blended model of education, in this proposal alone, is already an innovation in higher education, which combines classroom-based with online learning. Thus, the present study, which is part of a larger project, presents a contextualization of the models of blended teaching, a teaching trend in the 21st century. These models promote this combination of the use of technology, innovating in the premises of the classroom, and proposing new forms of assessment and learning experiences.

Innovative classroom practices, including the use of technology, have become the subject of study for many academics. Christensen, Horn, and Staker (2013, p.9) conceptualize blended education as: "[...] a formal education program in which a student learns, at least in part, through online learning. The student has some control over at least one of the following 
elements: time, place, mode and / or pace of study." Therefore, blended teaching seems to become an option to innovate in the traditional teaching model and to bring the online mode of study to the classroom.

The following guiding question is based on this research: How do learning experiences promote interconnectedness in blended learning environments through formative assessment? Thus, we started from the premise that sustained innovation can help improve the blended teaching model in the curriculum used by Anima. The hypothesis is that formative assessment in the online environment can provide, through learning experience, greater access to content by students. That happens because the proposal is linked to the classroom teacher, which constitutes the basis of study in blended education. The specific objectives are: to investigate blended teaching models, to understand the current model of blended teaching in Anima HEIs, to analyze and to test a proposal of inversion of assessment - summative to formative - in the online environment, using sustained innovation, in blended teaching in the discipline Entrepreneurship, at HEIs UNA, of Anima Group.

\section{SUMMATIVE AND FORMATIVE EVALUATIONS}

Arisen and systematized in the sixteenth century, school exams, which only in the twentieth century were updated, are perceived as learning assessment. The author of this change was Ralph Tyler, and he believed that this expression revealed educators' attention to student learning. For the author, assessment is a pedagogical action that reveals the level of understanding of knowledge and is more than simply giving a grade (what happens in school exams) (LUCKESI, 2013, apud SPINARDI and BOTH, 2017). However, in Brazil the theme is still relatively new, since it was only around the 1970s that the voice of learning assessments was expanded and today more (but not completely, because there are still schools that work with the old context exams) and in any type, in person or online (SPINARDI and BOTH, 2017).

Going further in the context of evaluation and its types, Both (2012) considers that it should have relevance to the online modality as well as classroom. If teaching evolves, it seems obvious that evaluation cannot be considered merely as an examination to indicate who goes ahead or not. The assessment needs to be reviewed and it should indicate to the student how it is developing (since blended teaching aims to promote student autonomy). And so, as Rodrigues (2015) reports, the feedback given to the student may be how he will find a learning orientation, including in this process the components involved, such as the teacher himself, the system used, among others.

This learning assessment has a crucial relationship with the personalization of teaching and student autonomy, in the case of the blended, because it has the advantage of using several online resources that can make the student walk his own path, from the returns from the feedback received. (SPINARDI and BOTH, 2017). To further clarify, it is necessary to report that assessments can have three functions in this process, diagnose (diagnostic assessment), form (formative assessment) and sum (summative assessment). As the authors clarify Silva, Deusa and Marques (2016) the diagnostic evaluation aims to identify if the students have knowledge and what they are to support the new acquired. In formative assessment the activities done by the students will guide their development and performance. And finally, by summative assessment students will be classified to advance or not to other levels. The same authors consider that the formative evaluation has great adherence to the blended model, and makes the school more complete, since they provide more assertive actions in face-to-face mode, considering that the teacher can evaluate online records and prospect for greater involvement in the classroom. In addition, they consider that the online environment can offer 
a higher interaction between the student and their learning process, favoring individualization (more related to blended teaching). The only caveat of this opinion is that in their research the authors did not use data with statistical metrics to prove the efficiency of the method (SCHIEHL, KEMCZINSKI, GASPARINI, 2017).

As it can also be seen in the research by Schiehl, Kemczinski, Gasparini (2017) other authors report on evaluations and their link with blended education, but few of them distinguish between the type of assessment and the most concrete reports are incisive in showing that evaluations should no longer be classificatory only in the context of the blended. The importance of learning and formative function assessments that have more complete roles must be considered. These evaluations make the teacher have a greater concentration on the individualization of his pedagogical interventions, which, as corroborated by Perrenoud (1999), can emphasize learning and adapt to teaching.

\section{ANIMA GROUP'S BLENDED LEARNING MODEL}

Anima's model is based on blended learning in its current curriculum (Anima Learning Ecosystem or E2A as it is called), which is a formal educational program in which a student learns, at least in part, through teaching online, with some element of student control over the time, place, path and pace of learning, and also partly in a supervised physical location, the classroom. In the description provided by Anima's HEI, the student attends a traditional, teacher-mediated school, where in this blended learning mode, online and classroom environments are interconnected to provide an integrated learning experience for the student. According to Hostt et al. (2018, p.189), "the teaching model was chosen since, through it, it is possible to provide a student-centered learning model". The model is based on the flipped classroom, that is, the concepts and some activities are performed in the online environment before the student attends the classroom, which then becomes the learning space through activities that promote the learning process role of the student. These activities are practical, investigative, reflective and most of which are performed in groups at face-to-face meetings.

According to the Flipped Classroom Field Guide (2014) report, for reverse classroom realization, it is necessary: that classroom activities involve a significant amount of questioning, problem solving and other active learning activities, so that the student can connect the concepts presented in the online environment; that students receive feedback immediately after the classroom activities; that students are encouraged to participate in both online and face-to-face activities, which are counted in the student's formal assessment; that both the material to be used online and the classroom learning environments are highly structured and well designed. Therefore, it is important to highlight that the Anima Group HEIs work with two types of evaluations in the disciplines that make up the E2A curriculum: summative and formative. Summative evaluation are assessments based on tests or questions to measure, through a test, whether the student has understood the concepts or performed from a taxonomy. The formative are assessments based on the learning process, which envision a student's evolution through individual or mainly group work.

\section{METHODOLOGICAL PROCEDURES}

The test was developed and applied in two classes, in the second semester of 2019 , in the Entrepreneurship discipline, which has 10 units in its programme content. It was proposed to reverse a (formative) assessment to be done in the online environment. This activity on the Ulife platform had the description of Learning Experience - Step 3 (Appendix A), which is in unit 6. Students had two weeks to complete it. The correction of this activity, by means of a rubric, was performed by both classroom and online teachers of each class. The purpose of the rubric was to develop criteria based on two indicators: Understanding of the activity and 
Knowledge of the content. These indicators help identify on a scale of 1 to 5 points how students responded to the learning experience as formative assessment.

\section{Data Analysis}

The data collected on the platform about student access to study content presents important information that leads to this verification. Comparatively, in both classes, the tables show students' access to units 5, 6 and 7, and the unit with a learning experience conducted by the classroom teacher and guided by the online teacher is number 6 . As it can be seen in Tables 1 and 2 below, in both classes, most students did not access the platform in units 5 and 7 of the course. It can be seen that in class 1 , with a total of 54 students, 41 students $(76 \%)$ did not access unit 5, and in unit 6 this number drops to 16 students (29\% did not access the unit). While in class 2, with 76 students, 31 students (41\%) did not access the material in unit 5, and in unit 6 this number drops to 6 (only 8\%). In unit 7 the number of non-hits goes up again. In a class of 54 students, 48 did not access unit 5, or 88\%. In the second class of 76 students, 52 did not access, that is, the majority, which are $68.4 \%$. This suggests that students feel safer with a familiar format (doing an online activity proposed by a classroom teacher), as they were willing to access the content and make their study effective.

Table 1 - Class 1 - Comparison of Accesses

\begin{tabular}{|c|c|c|c|}
\hline Tipo de Acesso & $\begin{array}{l}\text { Quantidade Alunos/ } \\
\text { Unidade } 5\end{array}$ & $\begin{array}{l}\text { Quantidade Alunos/ } \\
\text { Unidade } 6\end{array}$ & $\begin{array}{l}\text { Quantidade Alunos/ } \\
\text { Unidade } 7\end{array}$ \\
\hline Aluno não acessou esta atividade & 41 & 16 & 48 \\
\hline Visualizado $1 \mathrm{x}$ & 9 & 11 & 5 \\
\hline Visualizado $2 x$ & 2 & 7 & 0 \\
\hline Visualizado $3 x$ & 0 & 6 & 1 \\
\hline Visualizado $4 x$ & 1 & 6 & 0 \\
\hline Visualizado $5 x$ & 0 & 2 & 0 \\
\hline Visualizado $6 x$ ou mais & 1 & 6 & 0 \\
\hline Total Geral & 54 & 54 & 54 \\
\hline
\end{tabular}

Source: Prepared by the authors

Table 2 - Class 2 - Comparison of Accesses

\begin{tabular}{|c|c|c|c|}
\hline Tipo de Acesso & $\begin{array}{l}\text { Quantidade Alunos/ } \\
\text { Unidade } 5\end{array}$ & $\begin{array}{l}\text { Quantidade Alunos/ } \\
\text { Unidade } 6\end{array}$ & $\begin{array}{l}\text { Quantidade Alunos/ } \\
\text { Unidade } 7\end{array}$ \\
\hline Aluno não acessou esta atividade & 31 & 6 & 52 \\
\hline Visualizado $1 \mathrm{x}$ & 11 & 12 & 13 \\
\hline Visualizado $2 \mathrm{x}$ & 6 & 15 & 6 \\
\hline Visualizado $3 \mathrm{x}$ & 11 & 13 & 4 \\
\hline Visualizado $4 \mathrm{x}$ & 4 & 11 & 0 \\
\hline Visualizado $5 \mathrm{x}$ & 6 & 1 & 1 \\
\hline Visualizado $6 x$ ou mais & 7 & 18 & 0 \\
\hline Total Geral & 76 & 76 & 76 \\
\hline
\end{tabular}

Source: Prepared by the authors

However, it should be noted that accessing the platform does not necessarily mean that the student did the activity proposed by the teachers. They may simply have entered the content but not completed the activity and sent it to the online teacher. This is clear from the following data. In class 1 of 54 students, 37 students (69\%) performed / posted the activity in the online environment. In the second class of 76 students, 67 students (88\%) performed the activity. These data were provided by the online teacher who corrected the activity through the rubric. The number is slightly lower than content access, but it still represents a significant 
improvement compared to non-platform access in the previous unit of the learning experience as well as in the subsequent unit.

In the opinion of the online teachers, they consider that there was a good return of the students, with more elaborate answers than in the summative evaluation tests involving practical market experience applied to the content. They also consider that the group response in a diversified manner was important to exercise the student's way of experiencing the world of work, since in companies is the reality they will find. Regarding the feedback to be given to the students in the classroom, it was observed by the teachers that no more severe correction or even the need to redo the activity was necessary, since it was considered to be good for the great majority of students. Online feedback was given to students from the established headings. In a classroom meeting after the activity, the teachers asked the students if they had any difficulty in the learning experience and they reported only the question of being a group activity and needing more contacts between the students. However, this difficulty is also reported in purely presential works. For the teachers, both classroom and online, the activity had a good result as a formative assessment (content integration for procedural application). However, it should be noted that some points in the process still need to be optimized, such as preparing the platform to receive group work.

Still on the Ulife platform, an environment in which digital tools are used, it is interesting to note that it helps education by demonstrating new ways of learning, as explained by Romero (2010). To this end, it was noted that sustained innovation was demonstrated by the proposal to test the inversion of assessment - summative to formative - in the online environment. In this context, it is agreed that there was already innovation from the Anima Group, and in addition as Christensen, Horn and Staker (2013, p.2) point to sustained innovation, when "the market has historically defined what is good". Therefore, the proposal aimed to improve some aspect identified, for example, by the low access to content, so as to allow students to learn more. The learning experience conducted in the online environment was consistent with the learning objectives defined by the program content of Unit 6 of the Entrepreneurship discipline. This learning experience enabled the effectiveness of communication between online and classroom teachers, as well as the monitoring of students' learning progress through this formative assessment.

\section{FINAL CONSIDERATIONS}

The use of learning experiences allowed greater connectivity between online and classroom learning environments, as well as favoring students' learning through formative assessment. This, in turn, led to greater student access in the online learning environment. It is noteworthy that the nature of the proposed activity, which is investigative, also favored student engagement and high-level cognitive learning. Therefore, it is concluded that sustained innovation, caused by the change of the evaluation process, favored the flow between the presential and online learning environments, which can be applied and investigated in other hybrid models.

The blended teaching model used in the Anima Group HEIs is in the flipped classroom format, where students study content previously in an online environment and biweekly meetings are used for the activities. However, when it is proposed that students develop the learning experience in the online environment, it is noted that there is also an innovative way of integrating students, as they need to have more in-depth discussions to apply the content in the classroom proposed practice. This sustained innovation significantly demonstrates the need to rethink collaborative ways of studying and learning, making use of technology, which promote this evolution in teaching models, especially in the blended teaching model. 


\section{References}

ĂNIMA EDUCAÇÃO (Diretoria Acadêmica, Diretoria Adjunta de Currículo e Qualidade Acadêmica). Projeto Acadêmico Ǎnima. Publicação interna, 2017.

BACICH, Lilian.MORAN, José Manuel. Aprender e ensinar com foco na educação.Revista Pátio, no 25, junho, 2015, p. 45-47. Disponível em http://www2.eca.usp.br/moran/wpcontent/uploads/2015/07/hibrida.pdf. Acesso em $11 / 11 / 2019$.

BOTH, I. J. Avaliação: "voz da consciência" da aprendizagem. Curitiba: InterSaberes, 2012. (Série Avaliação Educacional).

BRASIL. Portaria $\mathrm{n}^{\circ} 4.059$, de 10 de dezembro de 2004. Autoriza a inclusão de disciplinas não presenciais em cursos superiores reconhecidos. Diário Oficial da União. Brasília, 13 dez. 2004. Disponível em: . Acesso em: $11 / 11 / 2019$

CHRISTENSEN. Clayton M., HORN, M. B.; STAKER, H. Ensino Híbrido: uma Inovação Disruptiva? Uma introdução à teoria dos híbridos. Traduzido para o Português por Fundação Lemann e Instituto Península. Maio/2013. Disponível em: https://www.christenseninstitute.org/publications/ensino-hibrido/ Acesso em 10/11/2019

HOSTT, A.C.G.S. et al. Programa Híbrido de Formação de Professores “Sala Mais". Pleiade, 12(25): 187-197, Dez., 2018 Edição Especial VI CIEd

MOORE, M.; KEARSLEY, G. Educação a Distância: uma visão integrada. São Paulo: Cengage Learning, 2008

MORAN, José Manuel. Os novos espaços de atuação do professor com as tecnologias. Revista Diálogo Educacional, vol. 4, núm. 12, mayo-agosto, 2004, pp. 1-9 Pontifícia Universidade Católica do Paraná Paraná, Brasil

RODRIGUES, L. A. Uma nova proposta para o conceito de blended learning. Interfaces da Educação, Paranaíba, v. 1, n. 3, p. 5-22, 2010. Disponível em: <http:// docplayer.com.br/1071699-Interfaces-da-educacao-5.html>. Acesso em: 12 nov.2019.

ROMERO, T. Educação sem distância: as tecnologias interativas na redução de distâncias em ensino e aprendizagem. São Paulo: Senac, 2010

SCHIEHL, Edson Pedro; KEMCZINSKI, Avanilde; GASPARINI, Isabela. As Perspectivas de Avaliar o Estudante no Ensino Híbrido. RENOTE, v. 15, n. 2. dezembro, 2017. Disponível em <https://www.seer.ufrgs.br/renote/article/viewFile/79280/46206>, acesso em 13/11/2019.

SPINARDI, Janine D., BOTH, Ivo J., Blended Learning: O Ensino Híbrido E A Avaliação Da Aprendizagem No Ensino Superior. B. Téc. Senac, Rio de Janeiro, v. 44, n. 1, jan./abr. 2018.

VALENTE, J. A. Blended learning e as mudanças no ensino superior: a proposta da sala. Educar em Revista, Curitiba, Brasil, Edição Especial n. 4/2014, p. 79-97. Editora UFPR 


\section{Learning Objectives:}

\section{APPENDIX A - UNIT 6 - LEARNING EXPERIENCE STEP 3}

- Conduct a survey with stakeholders in order to validate the construction carried out in the entrepreneurial methodology chosen.

- Create an MVP from the previous search.

\section{Connecting Knowledge Collaboratively}

Once Canvas is made from the chosen social problem - in the classroom, with the support of the classroom teacher - your team will have to do an interview and "walk out of the building" to get the answers from potential "clients". For this, the Lean Startup Model suggests GOOB, as mentioned in the material and whose concepts are reproduced below:

About the Get Out Of The Building (GOOB), Ries (apud Andreassi et al, 2017) wrote that once the entrepreneur has finished filling Canvas with his hypotheses, the next step is to validate such assumptions with the potential consumer. For this, the future entrepreneur should go out in the field, interviewing such consumers.

Of course, for this to happen, there is a whole criterion for performing such interviews. To validate Canvas, interviews are long (close to half an hour) because the most important is to understand the customer's views on the product or service. It is also vital to understand the customer context, preferences, needs, etc.

Each group should ask 10 questions for the interviews, 2 questions for each of the blocks below:

Customer segment;

Value offer;

Channels;

Relationship;

Key partnerships;

Asked the questions, the group should interview at least two people, scan the questions and answers and post in this environment.

Note: Discussions for the construction of the questionnaire should take place through virtual tools, such as whatsapp groups, skype or Zoom meetings, etc. 